\title{
Bromine in the tropical troposphere and stratosphere as derived from balloon-borne BrO observations
}

\author{
M. Dorf ${ }^{1}$, A. Butz ${ }^{2}$, C. Camy-Peyret ${ }^{3}$, M. P. Chipperfield ${ }^{4}$, L. Kritten ${ }^{1}$, and K. Pfeilsticker ${ }^{1}$ \\ ${ }^{1}$ Institut für Umweltphysik (IUP), University of Heidelberg, Heidelberg, Germany \\ ${ }^{2}$ SRON-Netherlands Institute for Space Research, Utrecht, The Netherlands \\ ${ }^{3}$ Laboratoire de Physique Moléculaire pour l'Atmosphère et l'Astrophysique (LPMAA), Université Pierre et Marie Curie, \\ Paris, France \\ ${ }^{4}$ Institute for Atmospheric Science, School of Earth and Environment, University of Leeds, Leeds, UK
}

Received: 22 May 2008 - Published in Atmos. Chem. Phys. Discuss.: 9 July 2008

Revised: 17 November 2008 - Accepted: 17 November 2008 - Published: 10 December 2008

\begin{abstract}
The first tropospheric and stratospheric (4 to $33 \mathrm{~km}) \mathrm{BrO}$ profile is presented for the inner tropics derived from balloon-borne DOAS (Differential Optical Absorption Spectroscopy) measurements. In combination with photochemical modelling, total stratospheric inorganic bromine $\left(\mathrm{Br}_{\mathrm{y}}\right)$ is deduced to be $(21.5 \pm 2.5) \mathrm{ppt}$ in 4.5-year-old air, probed in 2005. We derive a total contribution of $(5.2 \pm 2.5) \mathrm{ppt}$ from brominated very short-lived substances and inorganic product gases to stratospheric $\mathrm{Br}_{\mathrm{y}}$. Tropospheric $\mathrm{BrO}$ was found to be $<1 \mathrm{ppt}$. Our results are compared to two 3-D CTM SLIMCAT model runs, which differ in the lifetime of the bromine source gases, affecting the vertical distribution of $\mathrm{Br}_{\mathrm{y}}$ in the lower stratosphere. Bromine source gas measurements performed 10 days earlier (Laube et al., 2008), indicate a lower $\mathrm{Br}_{\mathrm{y}}$ of $(17.5 \pm 0.4)$ ppt. Potential reasons for this discrepancy are discussed.
\end{abstract}

\section{Introduction}

Stratospheric bromine has recently come into focus again, primarily due to the presumed importance of brominated very short-lived substances (VSLS), with a lifetime of less than 0.5 years, for ozone chemistry (Law and Sturges, 2007).

Previous studies exhibit various limitations to assess the different contributions to total stratospheric inorganic bromine $\left(\mathrm{Br}_{\mathrm{y}}\right)$. The temporally close observations of the major product gas (BrO) and source gases (Laube et al., 2008)

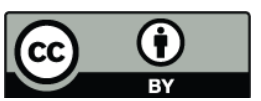

Correspondence to: $\mathrm{M}$. Dorf (marcel.dorf@iup.uni-heidelberg.de) at the same location attempt to overcome these limitations. Most studies did not cover the relevant source gases (SGs) and were not conducted within the region where the bulk of cross tropopause transport occurs, i.e., the tropical upper troposphere and lower stratosphere. Furthermore, investigation of only the SG injection may fall short in properly budgeting $\mathrm{Br}_{\mathrm{y}}$, since it ignores the contribution of $\mathrm{Br}$ tied to aerosols, and inorganic bromine species (e.g., $\mathrm{HBr}, \mathrm{BrO}$ ). Evidence for a sizeable inorganic product gas (PG) contribution has been found in recent field and theoretical studies and consequences for stratospheric ozone have been discussed (e.g., Pfeilsticker et al., 2000; Murphy and Thompson, 2000; Salawitch et al., 2005; Salawitch, 2006; Law and Sturges, 2007).

\section{Methodology}

Within the framework of the European ENVISAT satellite validation activities the LPMA/DOAS (Limb Profile Monitor of the Atmosphere/Differential Optical Absorption Spectroscopy) balloon payload probed the tropical troposphere, and lower and middle stratosphere. $\mathrm{Br}_{\mathrm{y}}$ was derived from measurements performed by the remote sensing LPMA/DOAS balloon payload (Camy-Peyret et al., 1993; Ferlemann et al., 2000). The LPMA/DOAS spectrometers cover the near-UV/visible (DOAS) and near-IR (LPMA) wavelength ranges, which are suitable for the detection of $\mathrm{O}_{3}, \mathrm{NO}_{2}, \mathrm{BrO}, \mathrm{IO}, \mathrm{OIO}, \mathrm{CH}_{4}, \mathrm{~N}_{2} \mathrm{O}$, and other trace-gases (e.g., Payan et al., 1998; Butz et al., 2006; Dorf et al., 2006a). The LPMA/DOAS payload was launched at tropical Teresina, Brazil, $\left(5.1^{\circ} \mathrm{S}, 42.9^{\circ} \mathrm{W}\right)$ on 17 June 2005 . It

Published by Copernicus Publications on behalf of the European Geosciences Union. 


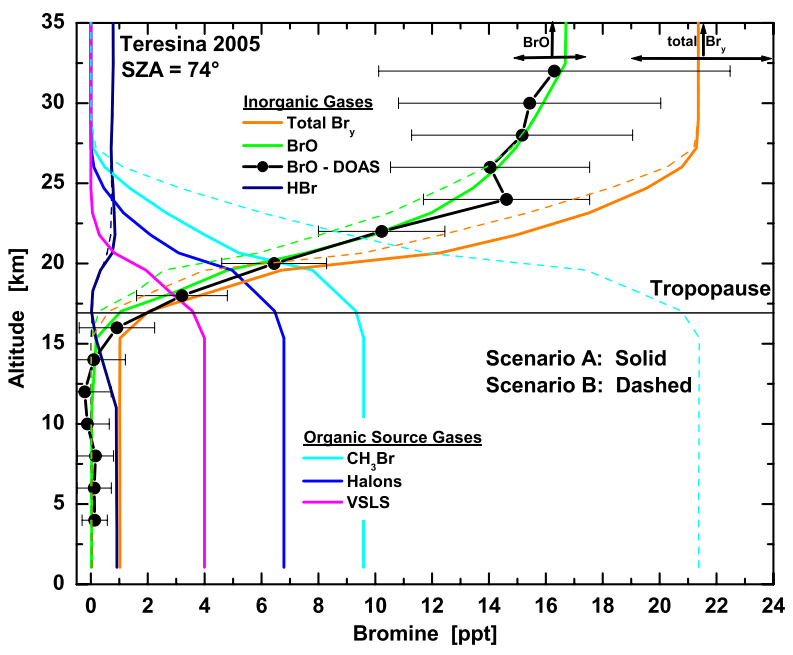

Fig. 1. Measured $\mathrm{BrO}$ (filled points) and modelled partitioning of inorganic stratospheric bromine species (lines) for the balloon flight at Teresina for a solar zenith angle (SZA) of $74^{\circ}$. BrO mixing ratios, inferred from Langley observations at balloon float altitude $(33 \mathrm{~km})$ (see Fig. 2 and text) and inferred total $\mathrm{Br}_{\mathrm{y}}$ are indicated by the data shown in the upper right corner. The 3-D CTM SLIMCAT assumes $\left(\mathrm{Br}_{\mathrm{y}}\right)=21.4 \mathrm{ppt}$ for the two model scenarios $\mathrm{A}$ and $\mathrm{B}$ as described in the text.

performed direct sun measurements during balloon ascent, from 2 to $33 \mathrm{~km}$ altitude, and during sunset at balloon float altitude $(33 \mathrm{~km})$ in solar occultation. The cold point tropopause was located at $17 \mathrm{~km}$.

Bromine monoxide $(\mathrm{BrO})$ is detected in the UV with the DOAS technique (Platt and Stutz, 2008) in the wavelength range from $346 \mathrm{~nm}$ to $360 \mathrm{~nm}$ as recommended by Aliwell et al. (2002). This wavelength range contains the UV vibration absorption bands $(4-0$ at $354.7 \mathrm{~nm}$, and $5-0$ at $348.8 \mathrm{~nm})$ of the $\mathrm{A}\left({ }^{2} \pi\right) \leftarrow \mathrm{X}\left({ }^{2} \pi\right)$ electronic transition of $\mathrm{BrO}$. The set of reference spectra used contains a $\mathrm{NO}_{2}$ reference spectrum for $\mathrm{T}=233 \mathrm{~K}$, and two $\mathrm{O}_{3}$ spectra at $\mathrm{T}=197 \mathrm{~K}$ and $\mathrm{T}=253 \mathrm{~K}$, in order to account for temperature effects. All $\mathrm{NO}_{2}$ and $\mathrm{O}_{3}$ spectra were recorded with the balloon spectrograph in the laboratory. The $\mathrm{BrO}$ reference is the absolute cross-section measured by Wahner et al. (1988), with the wavelength calibration taken from own laboratory measurements.

Profile information was obtained by a least-squares profile inversion technique (Maximum A Posteriori) (Rodgers, 2000). A more detailed description of the DOAS profile inversion can be found in Butz et al. (2006). The SCD values were smoothed with a Gaussian filter of $1.0 \mathrm{~km}$ width, but since the altitude grid for profile inversion is $2 \mathrm{~km}$, the results are not influenced significantly. Further details on the $\mathrm{BrO}$ DOAS-retrieval and the profile inversion can be found in Dorf et al. (2006a).

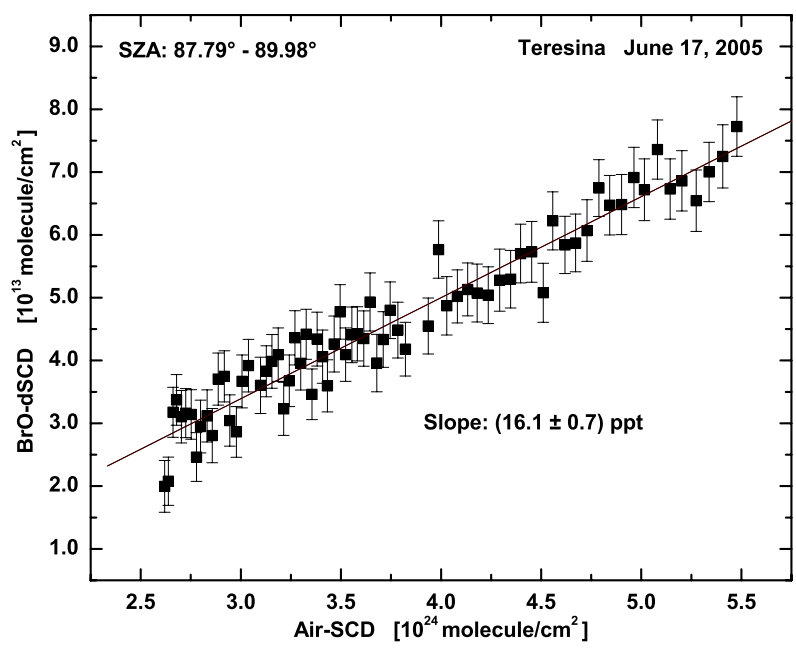

Fig. 2. Observed $\mathrm{BrO}$ absorption along the line-of-sight, taken from the balloon to the sun, for the balloon float altitude $(33 \mathrm{~km})$ measurements at Teresina. Total air-mass (Air-SCD) is calculated from the observation geometry (balloon position monitored by GPS, solar ephemerides and time) and measured temperature and pressure profiles. The slope of the line indicates the effective $\mathrm{BrO}$ mixing ratio above balloon float altitude.

In order to assess $\mathrm{Br}_{\mathrm{y}}$ we calculate the $\mathrm{BrO} / \mathrm{Br}_{\mathrm{y}}$ ratio using results from the 3-D off-line Chemical Transport Model (CTM) SLIMCAT (Chipperfield, 1999). SLIMCAT output, interpolated to the balloon location, was saved at 00:00 UT every two days. A 1-D model was then used to reconstruct the diurnal cycle for comparison with the observations. The stratospheric photochemistry is modelled on 20 potential temperature $(\Theta)$ levels between $\Theta=323 \mathrm{~K}(\simeq 9 \mathrm{~km})$ and $\Theta=1520 \mathrm{~K}(\simeq 42 \mathrm{~km})$. The 1 -D column model is initialised, at each height level, at 00:00 UT with 3-D CTM SLIMCAT model results. It is an updated version (using JPL-2006 kinetics; Sander et al., 2006) of the model used by, e.g., Butz et al. (2006) and includes a comprehensive set of all relevant gas-phase and heterogeneous reactions. Photolysis rates are interpolated with respect to pressure, temperature, overhead ozone and solar zenith angle (SZA) from a SLIMCAT lookup table where the actinic fluxes are calculated as recommended by Lary and Pyle (1991).

Like in previous studies (e.g., Dorf et al., 2006a) it is found useful to constrain the 1-D photochemical calculations with the measured abundances of $\mathrm{NO}_{2}$ and $\mathrm{O}_{3}$ taken from the same instrument (e.g., Butz et al., 2006). BrO reacts efficiently with $\mathrm{NO}_{2}$ to $\mathrm{BrONO}_{2}$, with the photolysis of $\mathrm{BrONO}_{2}$ being the most important back reaction during daytime. Therefore, stratospheric $\mathrm{BrO}$ is strongly dependent on $\mathrm{NO}_{2}$ and an appropriate scaling in the 1-D photochemical modelling reduces potential errors. 
For the measurement of brominated SGs and air-mass aging the whole-air-sampler BONBON collected samples on 8 June 2005 between 15.2 and $34 \mathrm{~km}$ altitude. The wholeair-sampler accommodates 15 individual stainless steel containers. The samples were analysed by gas chromatography/mass spectrometry for brominated source-gases $\mathrm{CH}_{3} \mathrm{Br}$, the halons, and brominated VSLS $\left(\mathrm{CHBr}_{3}, \mathrm{CH}_{2} \mathrm{Br}_{2}\right.$, $\mathrm{CH}_{2} \mathrm{BrCl}, \mathrm{CHBrCl}_{2}$ and $\mathrm{CHBr}_{2} \mathrm{Cl}$ ). Details are described by Laube et al. (2008).

\section{Results and discussion}

Maximum $\mathrm{BrO}$ mixing ratios of about $16 \mathrm{ppt}$ were detected at and above balloon float altitude at $33 \mathrm{~km}$ (Fig. 1). A Langley plot is shown in Fig. 2, where the measured $\mathrm{BrO}$ absorption is analysed as a function of the calculated total airmass at balloon float altitude for a solar zenith angle (SZA) range between $87.8^{\circ}$ and $90.0^{\circ}$. The slope of this correlation, (16.1 \pm 0.7$) \mathrm{ppt}$, indicates the effective $\mathrm{BrO}$ mixing ratio above balloon float altitude. Stratospheric $\mathrm{Br}_{\mathrm{y}}$ is calculated from the modelled $\mathrm{BrO} / \mathrm{Br}_{\mathrm{y}}$ partitioning weighted with the relative $\mathrm{BrO}$ concentration in each atmospheric layer. This ratio can be obtained by considering the bromine chemistry above balloon float altitude at daytime. In the sunlit upper stratosphere, the most important bromine reactions ( $\geq 90 \%)$ are (a) the photolysis of $\mathrm{BrO}$ and (b) the reaction of atomic bromine with $\mathrm{O}_{3}$. Inaccuracies in this photochemical scheme are due to the $\mathrm{BrO}$ cross section, the quantum yield for $\mathrm{BrO}$ photo-dissociation, the rate reaction coefficient $\mathrm{k}_{\mathrm{Br}+\mathrm{O}_{3}}$ and the ozone concentration. From mean $\mathrm{BrO} / \mathrm{Br}_{\mathrm{y}}=0.75$ we infer $\mathrm{Br}_{\mathrm{y}}=(21.5 \pm 2.5) \mathrm{ppt}$. The total error $(1-\sigma)$ represents the precision as well as uncertainties in the $\mathrm{BrO}$ cross section $( \pm 8 \%)$ and the photochemical correction used to convert $\mathrm{BrO}$ to $\mathrm{Br}_{\mathrm{y}}$ $( \pm 8 \%)$ (see Dorf et al., 2006a).

In the lower and middle troposphere $\mathrm{BrO}$ concentrations are compatible with zero within the uncertainties (around 1 ppt, depending on altitude - see Fig. 1). The very low, or even negligible, $\mathrm{BrO}$ concentrations $(<1 \mathrm{ppt})$ for the lower, middle and upper troposphere agree with recent studies of (Schofield et al., 2004, 2006), but largely challenges other findings (Richter et al., 1998; Fitzenberger et al., 2000; Van Roozendael et al., 2002; Salawitch et al., 2005; Hendrick et al., 2007; Fietkau et al., 2007; Theys et al., 2007). With regard to these contrasting findings, it is not clear whether the bromine released during the breakup process of the VSLS in the troposphere either (1) quickly reacts into less reactive forms of bromine $\left(\mathrm{HBr}, \mathrm{HOBr}\right.$, and $\left.\mathrm{BrONO}_{2}\right)$ without being efficiently activated on particle surfaces (von Glasow et al., 2004; Iraci et al., 2005), or (2) is permanently taken-up by particles and eventually washed-out, or (3) whether the reverse is true and we (and others) simply missed probing the right air-masses in the tropics, in which the brominated PGs can efficiently become activated into $\mathrm{BrO}$.

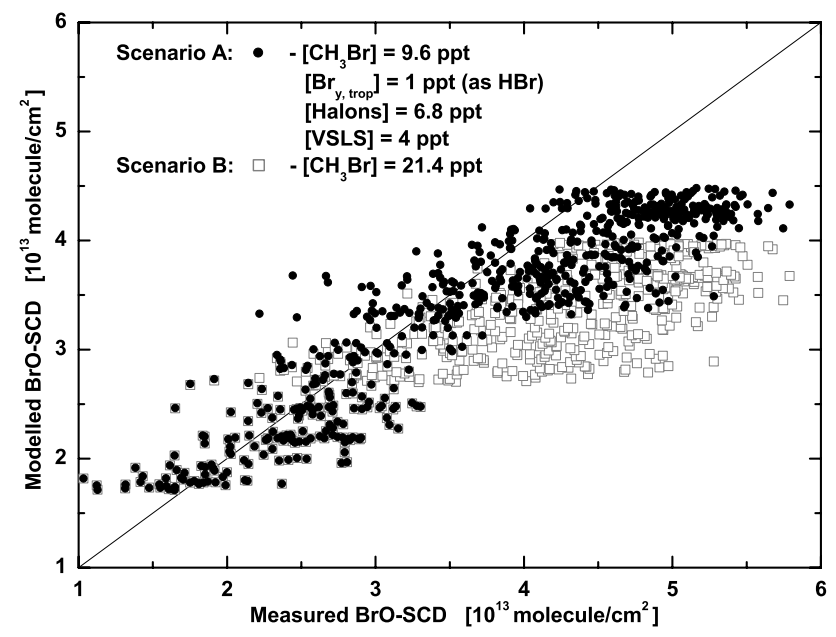

Fig. 3. Correlation plot for measured versus modelled BrO SCDs during ascent for the Teresina 2005 balloon flight. The two model runs are described in the text.

For the local tropopause $(17 \mathrm{~km})$ the observed $\mathrm{BrO}$ concentration is $(2.0 \pm 1.5)$ ppt. Above the tropopause, $\mathrm{BrO}$ rapidly increases with height as shown in Fig. 1 $\mathrm{BrO}=(3.2 \pm 1.6) \mathrm{ppt}$ at $18 \mathrm{~km}$. This rapid increase of $\mathrm{BrO}$ indicates that a considerable amount of brominated species with a rather short lifetime and PGs are injected, which readily release bromine atoms. A model comparison supports this finding. We use two SLIMCAT model runs (Feng et al., 2007) denoted Scenario A and B, in order to explain the $\mathrm{BrO}$ observations during balloon ascent below $25 \mathrm{~km}$. Scenario A differentiates between the individual contributions of $\mathrm{CH}_{3} \mathrm{Br}$ (9.6 ppt), the halons (6.8 ppt), and VSLS (4 ppt as $\mathrm{CH}_{2} \mathrm{Br}_{2}$ ) plus PGs (1 ppt as $\mathrm{HBr}$ ). In Scenario B the only source gas in the model is $\mathrm{CH}_{3} \mathrm{Br}$, solely accounting for $21.4 \mathrm{ppt}$ of bromine. The correlation between the measured versus modelled BrO slant-column densities are plotted in Fig. 3 for balloon ascent measurements. The better agreement between Scenario A and the measurements can also be observed in Fig. 1 where the solid lines represent Scenario A and the dashed lines Scenario B. Implications of this composition of brominated SGs for ozone loss and model details are discussed in Feng et al. (2007). In the stratosphere the SG concentrations rapidly decrease with height as the air-masses ascend further. Photolysis and reactions with $\mathrm{OH}$ lead to the formation of inorganic bromine species. Thereby ozone depleting bromine atoms are released on a timescale that is on the order of the individual substance's lifetime. Thus the released bromine atoms are found in the inorganic PGs. Once the air-masses have reached the tropical middle stratosphere, all SGs are destroyed (Fig. 1). Our data suggest complete destruction of the brominated SGs between 27 to $30 \mathrm{~km}$ in the tropical stratosphere, in agreement with Laube et al. (2008) who found no SG signal above $30 \mathrm{~km}$. 


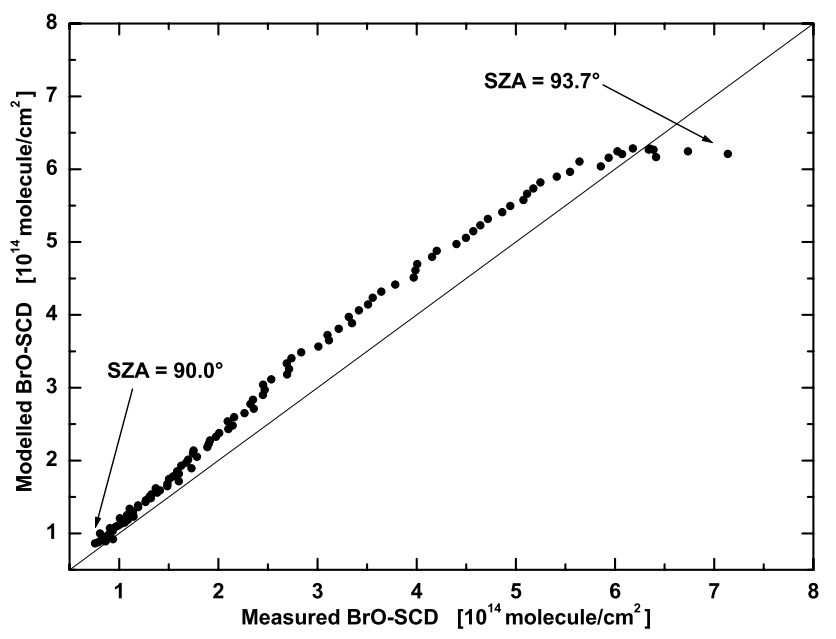

Fig. 4. Correlation plot for measured versus modelled BrO SCDs for occultation measurements between $90.0^{\circ}$ and $93.7^{\circ} \mathrm{SZA}$.

One should note that the inclusion of halons in Scenario $\mathrm{B}$ (keeping total $\mathrm{Br}_{\mathrm{y}}$ at $21.4 \mathrm{ppt}$ ) would further slow down the increase of $\mathrm{Br}_{\mathrm{y}}$ with altitude. This would enlarge the discrepancy between the two model scenarios. Therefore the inclusion of VSLS in Scenario A not only compensates for the slower increase of $\mathrm{Br}_{\mathrm{y}}$ due to the consideration of halons in the model (instead of only $\mathrm{CH}_{3} \mathrm{Br}$ as in Scenario B), but leads to an even more rapid increase of $\mathrm{Br}_{\mathrm{y}}$ above the tropopause, which is needed to explain our observations.

Furthermore, the modelled and measured $\mathrm{BrO}$ values during solar occultation $\left(\mathrm{SZA}>90^{\circ}\right)$ at balloon float do not match (this corresponds to tangent-heights of the line-ofsights through the atmosphere from $33 \mathrm{~km}$ down to $18 \mathrm{~km}$ ). The discrepancy applies to both model scenarios, since $\mathrm{Br}_{\mathrm{y}}$ is equal in the relevant altitude range. This is unlike previous comparisons (e.g., Harder et al., 2000) at high and mid-latitudes. Modelled values are up to $15 \%$ larger for $\mathrm{SZA}>90^{\circ}$ (see Fig. 4). Scaling of $\mathrm{NO}_{2}$ only has a small effect on the $\mathrm{BrO}$ profile and does not explain the observed discrepancy. It can be speculated whether the $\mathrm{HO}_{\mathrm{x}}$ or $\mathrm{ClO}_{\mathrm{x}}$ chemistry and therefore $\mathrm{HOBr}$ or $\mathrm{BrCl}$ play a more important role than at mid and high-latitudes. This issue will need further investigation with future tropical data in combination with results from other balloon or satellite observations.

A total $\mathrm{Br}_{\mathrm{y}}$ of $(17.5 \pm 0.4)$ ppt was derived from the organic SG measurements of the BONBON whole-air-sampler (Laube et al., 2008) - hereafter called $\mathrm{Br}_{\mathrm{y}}^{\text {org }}$. Besides the long-lived brominated $\mathrm{SGs}, \mathrm{CH}_{3} \mathrm{Br}$ and the halons, the 5 measured VSLS $\left(\mathrm{CHBr}_{3}, \mathrm{CH}_{2} \mathrm{Br}_{2}, \mathrm{CH}_{2} \mathrm{BrCl}, \mathrm{CHBrCl}_{2}\right.$ and $\mathrm{CHBr}_{2} \mathrm{Cl}$ ) contributed (1.25 \pm 0.16$)$ ppt to $\mathrm{Br}_{\mathrm{y}}^{\text {org }}$. Thus the inferred $\mathrm{Br}_{\mathrm{y}}$ from inorganic $\mathrm{BrO}\left(\mathrm{Br}_{\mathrm{y}}\right.$ in $)$ is significantly larger, by (4.0 \pm 2.9$) \mathrm{ppt}$, than what can be expected from the measured SGs. Although the difference is quite significant and most likely systematic, the values lie almost within the

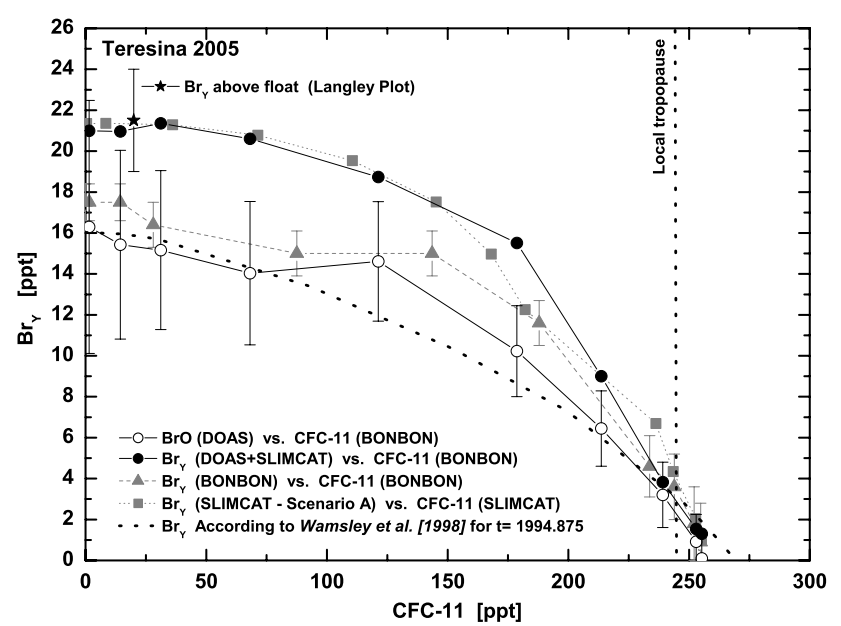

Fig. 5. Correlation between $\mathrm{Br}_{\mathrm{y}}$ and CFC-11 from balloon data and modelling.

stated 1- $\sigma$ uncertainties. Ko et al. (1997) suggested a direct $\mathrm{PG}$ injection into the stratosphere, which could be due to bromine tied in aerosols (Murphy and Thompson, 2000) or in gaseous form (e.g., $\mathrm{HBr}, \mathrm{Br}, \mathrm{BrO}$...). Comparing $\mathrm{Br}_{\mathrm{y}}^{\text {in }}$ to tropospheric trend measurements of $\mathrm{CH}_{3} \mathrm{Br}$ and the halons taken from Montzka et al. (2003), where no tropospheric loss of $\mathrm{CH}_{3} \mathrm{Br}$ is assumed, yields a VSLS plus PG injection of $5.2 \mathrm{ppt}$ into the stratosphere (see also Table 1).

Further reasons for the discrepancy between $\mathrm{Br}_{\mathrm{y}}^{\text {in }}$ and $\mathrm{Br}_{\mathrm{y}}^{\text {org }}$ could be the uncertainties in the SG absolute calibration scales used by different laboratories (Laube et al., 2008) and that the contribution of VSLS varies with geolocation and time. Stronger convection in combination with areas of stronger VSLS sources on the ground, could lead to higher $\mathrm{Br}_{\mathrm{y}}$. Furthermore, the whole-air-sampler VSLS concentrations represent a local budget for the probed area and time in the tropical tropopause layer. In contrast, $\mathrm{Br}_{\mathrm{y}}^{\text {in }}$ is based on measurements of 4.5 year old air in the longitudinally well mixed middle stratosphere and might comprise a different VSLS contribution. Here we used the whole-air-sampler $\mathrm{N}_{2} \mathrm{O}$ measurements for air-mass aging (Engel et al., 2002).

Figure 5 gives the correlation between $\mathrm{Br}_{\mathrm{y}}$ and the tracer CFC-11, similar to the study of Wamsley et al. (1998). CFC11 was taken from the whole-air-sampler, which flew 9 days earlier, and interpolated in altitude, in order to match the DOAS altitude grid. The Wamsley et al. (1998) correlation for November 1994 is plotted as well. Since stratospheric CFC-11 has declined while $\mathrm{Br}_{\mathrm{y}}$ has continued to increase, the values from Wamsley et al. (1998) are not directly comparable with our findings.

A similar study for high-latitudes, involving the same instruments, was performed at Kiruna, Sweden $\left(67.9^{\circ} \mathrm{N}, 22.1^{\circ} \mathrm{E}\right)$ in winter 1999 (Pfeilsticker et al., 2000). Using the Langley method to derive $\mathrm{Br}_{\mathrm{y}}^{\text {in }}=(19.9 \pm 2.5) \mathrm{ppt}$, the analysis indicates 
Table 1. Estimated contribution of the very short-lived substances (VSLS) and product-gases (PGs) derived from organic source-gas (SG) and inorganic $\mathrm{Br}_{\mathrm{y}}$ measurements.

\begin{tabular}{|c|c|c|}
\hline & Kiruna 1999 & Teresina 2005 \\
\hline Air-mass age at balloon-float (years) & $6.0 \pm 1$ & $4.5 \pm 1$ \\
\hline $\mathrm{CH}_{3} \mathrm{Br}(\mathrm{ppt})^{\mathrm{a}}$ & 9.3 & 8.8 \\
\hline Halons (ppt) ${ }^{a}$ & 5.8 & 7.5 \\
\hline $\mathrm{Br}_{\mathrm{y}}$ from $\mathrm{BrO}, \mathrm{Br}_{\mathrm{y}}^{\text {in }}(\mathrm{ppt})$ & $19.9 \pm 2.5^{\mathrm{b}}$ & $21.5 \pm 2.5$ \\
\hline Inferred VSLS + PG injection, i.e. $\mathrm{Br}_{\mathrm{y}}^{\text {in }}-\left(\mathrm{CH}_{3} \mathrm{Br}+\right.$ halons $)(\mathrm{ppt})$ & 4.7 & 5.2 \\
\hline $\mathrm{Br}_{\mathrm{y}}$ from SG measurements, $\mathrm{Br}_{\mathrm{y}}^{\mathrm{org}}(\mathrm{ppt})$ & $18.4(-1.5 /+1.8)$ & $17.5 \pm 0.4$ \\
\hline Measured VSL - SGs at stratospheric entry level (ppt) & $2.6 \pm 0.6$ & $1.25 \pm 0.16$ \\
\hline $\begin{array}{l}\text { Potential maximum PG injection assuming a locally balanced bro } \\
\text { i.e. } \mathrm{Br}_{\mathrm{y}}^{\text {in }}-\left(\mathrm{CH}_{3} \mathrm{Br}+\text { halons+measured VSLS }\right)(\mathrm{ppt})\end{array}$ & $2.1 \pm 2.6$ & $4.0 \pm 2.5$ \\
\hline
\end{tabular}

\footnotetext{
${ }^{\text {a }}$ Surface $\mathrm{CH}_{3} \mathrm{Br}$ and halon data are from Montzka et al. (2003). We assume no tropospheric loss of $\mathrm{CH}_{3} \mathrm{Br}$.

b Value based on the Langley method as compared to the SCD-/profile comparison of Pfeilsticker et al. (2000).

$\mathrm{c}$ This is more likely true for the tropics, where most of the upward flux into the stratosphere occurs, than for high-latitudes.
}

a VSLS plus PG injection of $4.7 \mathrm{ppt}$ (Dorf et al., 2006b). A reanalysis of the BrO-SCDs and comparison with modelled BrO-SCD values, as shown by Pfeilsticker et al. (2000), yields a $\mathrm{Br}_{\mathrm{y}}$ of $(19.5 \pm 2.5) \mathrm{ppt}$, i.e., $2 \mathrm{ppt}$ smaller than in the Pfeilsticker et al. (2000) study (21.5 ppt). Here we improved the calculation of the residual amount of $\mathrm{BrO}$ in the reference spectrum and scaled $\mathrm{NO}_{2}$ in the photochemical model to our balloon observations, in order to get the correct bromine partitioning and therefore $\mathrm{Br}_{\mathrm{y}}$. Table 1 summarises the values of the Kiruna (1999) and Teresina (2005) studies using the $\mathrm{Br}_{\mathrm{y}}^{\text {in }}$ derived with the Langley method.

Assuming that no unknown SGs contributed to $\mathrm{Br}_{\mathrm{y}}^{\mathrm{in}}$ and that there are no large temporal variations in the VSLS, we can calculate a potential maximum PG injection for a locally balanced bromine-budget, with $2.1 \mathrm{ppt}$ for Kiruna 1999 and $4.0 \mathrm{ppt}$ for Teresina 2005 (see Table 1). In the tropics, with a net upward mass flux and the primary tropospherestratosphere exchange, these assumptions are more justified than for high-latitudes. There is certainly the need for comprehensive studies in the future, which include dynamical analysis of the transport of air masses, as well as SG and PG measurements, from the ground to the lower stratosphere.

The sum for the VSLS and PG injection compares reasonably well with recent, mostly satellite-based $\mathrm{BrO}$ studies, and ranges between 0 and 10.4 ppt. Here the average and the range of the central values of the considered studies is 5 ppt and (3-8) ppt, respectively (see Table $2-8$ in Law and Sturges, 2007 and references therein, and Hendrick et al., 2007). Most of these studies are inherently less accurate than those possible by balloon-borne spectroscopic $\mathrm{BrO}$ observations, and suffer from the lack of air-mass aging and simultaneous VSLS measurements for the investigated air-masses.

\section{Conclusions and summary}

This study presents the first inner tropical $\mathrm{BrO}$ profile from the troposphere up to the middle stratosphere (4 to $33 \mathrm{~km}$ ). $\mathrm{A} \mathrm{Br} \mathrm{y}_{\mathrm{in}}^{\mathrm{in}}$ concentration of $(21.5 \pm 2.5) \mathrm{ppt}$ was derived from balloon-borne $\mathrm{BrO}$ measurements in combination with photochemical modelling. A comparison with different model scenarios of the 3-D CTM SLIMCAT, differing in the lifetimes of the bromine source gases, shows the need for a significant VSLS and PG injection into the stratosphere. Our $\mathrm{Br}_{\mathrm{y}}^{\mathrm{in}}$ indicates a total contribution of the VSLS and PGs of 5.2 ppt. Temporally close organic SG measurements, including VSLS, indicate a $\mathrm{Br}_{\mathrm{y}}^{\mathrm{org}}$ of $(17.5 \pm 0.4) \mathrm{ppt}$, which is significantly lower than $\mathrm{Br}_{\mathrm{y}}^{\mathrm{in}}$. The difference between $\mathrm{Br}_{\mathrm{y}}^{\text {in }}$ and $\mathrm{Br}_{\mathrm{y}}^{\text {org }}$ can be explained if accounting for calibration uncertainties, additional unidentified brominated VSLS, the variability of VSLS in time and space (Laube et al., 2008), and considering a further source of stratospheric bromine (e.g., PG injection).

Our result on reactive bromine and the PG abundance in the troposphere is inconclusive. Tropospheric $\mathrm{BrO}$ is compatible with $0 \mathrm{ppt}$ and $<1 \mathrm{ppt}$ within the uncertainties. This is in agreement with studies of (Schofield et al., 2004, 2006), but contradicts other findings (e.g., Richter et al., 1998; Fitzenberger et al., 2000; Salawitch et al., 2005; Theys et al., 2007). Future research is needed with more sensitive instrumentation and sophisticated models in order to reveal the role that bromine plays for the photochemistry of the troposphere and UT/LS region.

Acknowledgements. Funding for this study came from the Bundesministerium für Bildung und Forschung (BMBF) (contract DLR-50EE0017) and the European Union (EU) through the SCOUT-O3 project (contract 505390-GOCE-CT-2004). The SLIMCAT modelling was supported by the NERC, UK. We thank 
the CNES 'equipe nacelles pointées' and the balloon team from Aire sur l'Adour/France without which the balloon flights would not have been possible. We also thank our colleagues from the LPMA balloon team (P. Jeseck, I. Pepin and Y. Té) for the successful cooperation, and Ross J. Salawitch and Laurie J. Kovalenko for their helpful comments. J. C. Laube and A. Engel from the University of Frankfurt, and W. T. Sturges from the University of East Anglia are especially acknowledged for their data provision and cooperation.

Edited by: A. Richter

\section{References}

Aliwell, S., Van Roozendael, M., Johnston, P., Richter, A., Wagner, T., Arlander, D., Burrows, J., Fish, D., Jones, R., Tornkvist, K., Lambert, J.-C., Pfeisticker, K., and Pundt, I.: Analysis for BrO in zenith-sky spectra: An intercomparison exercise for analysis improvement, J. Geophys. Res., 107, doi:10.1029/2001JD000329, 4199 pp., 2002.

Butz, A., Bösch, H., Camy-Peyret, C., Chipperfield, M. P., Dorf, M., Dufour, G., Grunow, K., Jeseck, P., Kühl, S., Payan, S., Pepin, I., Pukite, J., Rozanov, A., von Savigny, C., Sioris, C., Wagner, T., Weidner, F., and Pfeilsticker, K.: Inter-comparison of Stratospheric $\mathrm{O}_{3}$ and $\mathrm{NO}_{2}$ abundances retrieved from balloonborne direct sun observations and Envisat/SCIAMACHY limb measurements, Atmos. Chem. Phys., 5, 10 747-10 797, 2006, http://www.atmos-chem-phys.net/5/10747/2006/.

Camy-Peyret, C., Flaud, J.-M., Perrin, A., Rinsland, C. P., Goldman, A., and Murcray, F.: Stratospheric $\mathrm{N}_{2} \mathrm{O}_{5}, \mathrm{CH}_{4}$ and $\mathrm{N}_{2} \mathrm{O}$ profiles from IR solar occultation spectra, J. Atmos. Chem., 16, 31-40, 1993.

Chipperfield, M. P.: Multiannual simulations with a threedimensional chemical transport model, J. Geophys. Res., 104, D1, 1781-1805, 1999.

Dorf, M., Bösch, H., Butz, A., Camy-Peyret, C., Chipperfield, M. P., Engel, A., Goutail, F., Grunow, K., Hendrick, F., Hrechanyy, S., Naujokat, B., Pommereau, J.-P., Van Roozendael, M., Sioris, C., Stroh, F., Weidner, F., and Pfeilsticker, K.: Balloonborne stratospheric $\mathrm{BrO}$ measurements: comparison with Envisat/SCIAMACHY BrO limb profiles, Atmos. Chem. Phys., 6, 2483-2501, 2006a,

http://www.atmos-chem-phys.net/6/2483/2006/.

Dorf, M., Butler, J. H., Butz, A., Camy-Peyret, C., Chipperfield, M. P., Kritten, L., Montzka, S. A., Simmes, B., Weidner, F., and Pfeilsticker, K.: Long-term observations of stratospheric bromine reveal slow down in growth, Geophys. Res. Lett., 33, L24803, doi:10.1029/2006GL027714, 2006b.

Engel, A., Strunk, M., Müller, M., Haase, H.-P., Poss, C., Levin, I., and Schmidt, U.: Temporal development of total chlorine in the high-latitude stratosphere based on reference distributions of mean age derived from $\mathrm{CO}_{2}$ and $\mathrm{SF}_{6}$, J. Geophys. Res., 107, 2002.

Feng, W., Chipperfield, M. P., Dorf, M., Pfeilsticker, K., and Ricaud, P.: Mid-latitude ozone changes: studies with a 3-D CTM forced by ERA-40 analyses, Atmos. Chem. Phys., 7, 2357-2369, 2007 ,

http://www.atmos-chem-phys.net/7/2357/2007/.
Ferlemann, F., Bauer, N., Fitzenberger, R., Harder, H., Osterkamp, H., Perner, D., Platt, U., Scheider, M., Vradelis, P., and Pfeilsticker, K.: Differential optical absorption spectroscopy instrument for stratospheric balloon-borne trace gas studies, Appl. Optics, 39, 2377-2386, 2000.

Fietkau, S., Medeke, T., Richter, A., Sheode, N., Sinnhuber, B.-M., Wittrock, F., Theys, N., van Roozendael, M., and Burrows, J. P.: Ground-based measurements of tropospheric and stratospheric bromine monoxide above Nairobi $\left(1^{\circ} \mathrm{S}, 36^{\circ} \mathrm{E}\right)$, Atmos. Chem. Phys. Discuss., 7, 6527-6555, 2007, http://www.atmos-chem-phys-discuss.net/7/6527/2007/.

Fitzenberger, R., Bösch, H., Camy-Peyret, C., Chipperfield, M. P., Harder, H., Platt, U., Pyle, J., Wagner, T., and Pfeilsticker, K.: First profile measurement of tropospheric BrO, Geophys. Res. Lett., 27, 2921-2924, 2000.

Harder, H., Bösch, H., Camy-Peyret, C., Chipperfield, M. P., Fitzenberger, R., Payan, S., Perner, D., Platt, U., Sinnhuber, B.-M., and Pfeilsticker, K.: Comparison of measured and modeled stratospheric BrO: implications for the total amount of stratospheric bromine, Geophys. Res. Lett., 27(22), 3695-3698, 2000.

Hendrick, F., van Roozendael, M., Chipperfield, M. P., Dorf, M., Goutail, F., Yang, X., Fayt, C., Hermans, C., Pfeilsticker, K., Pommereau, J. P., Pyle, J., Theys, N., and de Mazière, M.: Retrieval of stratospheric and tropospheric $\mathrm{BrO}$ profiles and columns using ground-based zenith-sky DOAS observations at Harestua, $60^{\circ} \mathrm{N}$, Atmos. Chem. Phys., 7, 4869-4885, 2007, http://www.atmos-chem-phys.net/7/4869/2007/.

Iraci, L. T., Michelsen, R. R., Ashbourn, S. F. M., Rammer, T. A., and Golden, D. M.: Uptake of hypobromous acid (HOBr) by aqueous sulfuric acid solutions: low-temperature solubility and reaction, Atmos. Chem. Phys., 5, 1577-1587, 2005, http://www.atmos-chem-phys.net/5/1577/2005/.

Ko, M. K. W., Sze, N. D., Scott, C. J., and Weissenstein, D. K.: On the relation between chlorine/bromine loading and short-lived tropospheric source gases, J. Geophys. Res., 102, 25 507-25 517, 1997.

Lary, D. J. and Pyle, J. A.: Diffuse radiation, twilight and photochemistry, J. Atmos. Chem., 373-392, 1991.

Laube, J. C., Engel, A., Boenisch, H., Möbius, T., Worton, D. R., Sturges, W. T., Grunow, K., and Schmidt, U.: Contribution of very short-lived organic substances to stratospheric chlorine and bromine in the tropics - a case study, Atmos. Chem. Phys. Discuss., 8, 8491-8515, 2008,

http://www.atmos-chem-phys-discuss.net/8/8491/2008/.

Law, K. S. and Sturges, W. T.: Chapter 2 ("Halogenated very shortlived substances") in World Meteorological Organization, Scientific Assessment of Ozone Depletion: 2006, Global Ozone Research and Monitoring Project - Report No.50, Geneva, Switzerland, 2007.

Montzka, S., Butler, J., Hall, B., Mondell, D., and Elkins, J.: A decline in tropospheric organic bromine, Geophys. Res. Lett., 30, 15, 1826-1829, 2003.

Murphy, D. M. and Thompson, D. S.: Halogen ions and $\mathrm{NO}^{+}$in the mass spectra of aerosols in the upper troposphere and lower stratosphere, Geophys. Res. Lett., 27, 3217-3220, 2000.

Payan, S., Camy-Peyret, C., Jeseck, P., Hawat, T., Durry, G., and Lefèvre, F.: First direct simultaneous $\mathrm{HCl}$ and $\mathrm{ClONO}_{2}$ profile measurements in the artic vortex, Geophys. Res. Lett., 25, 14, 2663-2666, 1998. 
Pfeilsticker, K., Sturges, W. T., Bösch, H., Camy-Peyret, C., Chipperfield, M. P., Engel, A., Fitzenberger, R., Müller, M., Payan, S., and Sinnhuber, B.-M.: Lower stratospheric organic and inorganic bromine budget for the Artic winter 1998/99, Geophys. Res. Lett., 27, 20, 3305-3308, 2000.

Platt, U. and Stutz, J.: Differential Optical Absorption Spectroscopy (DOAS), Principles and Applications, ISBN 978-3-540-21193-8, Springer Verlag, Heidelberg, 2008.

Richter, A., Wittrock, F., Eisinger, M., and Burrows, J. P.: GOME observations of tropospheric BrO in Northern Hemispheric spring and summer 1997, Geophys. Res. Lett., 25, 14, 2683-2686, 1998.

Rodgers, C.: Inverse methods for atmospheric sounding, World Scientific, Singapore, New Jersey, London, Hongkong, ISBN-9789810227401, 2000.

Salawitch, R. J., Weisenstein, D. K., Kovalenko, L. J., Sioris, C. E., Wennberg, P. O., Chance, K., Ko, M. K. W., and McLinden, C. A.: Sensitivity of ozone to bromine in the lower stratosphere, Geophys. Res. Lett., 32, L05811, doi:10.1029/2004GL021504, 2005.

Salawitch, R. J.: Atmospheric chemistry: biogenic bromine, Nature, 439, 275-277, 2006.

Sander, S. P., Finlayson-Pitts, B. J., Friedl, R. R., Golden, D. M., Huie, R. E., Keller-Rudek, H., Kolb, C. E., Kurylo, M. J., Molina, M. J., Moortgart, G. K., Orkin, V. L., Ravishankara, A. R., and Wine, P. H.: Chemical Kinetics and Photochemical Data for Use in Atmospheric Studies, Evaluation Number 15, JPL Publication 06-2, Jet Propulsion Laboratory, Pasadena, USA, 2006.

Schofield, R., Kreher, K., Connor, B. J., Johnston, P. V., Thomas, A., Shooter, D., Chipperfield, M. P., Rodgers, C. D., and Mount, G. H.: Retrieved tropospheric and stratospheric BrO columns over Lauder, New-Zealand, J. Geophys. Res., 109, D14, 304, 2004.
Schofield, R., Johnston, P. V., Thomas, A., Kreher, K., Connor, B. J., Wood, S., Shooter, D., Chipperfield, M. P., Richter, A., von Glasow, R., and Rodgers, C. D.: Tropospheric and stratospheric BrO columns over Arrival Heights, Antarctica, 2002, J. Geophys. Res., 111, D10, D22310, 2006.

Theys, N., Van Roozendael, M., Hendrick, F., Fayt, C., Hermans, C., Barray, J.-L., Goutail, F., Pommereau, J.-P., and De Mazière, M.: Retrieval of stratospheric and tropospheric BrO columns from multi-axis DOAS measurements at Reunion Island $\left(21^{\circ} \mathrm{S}\right.$, $56^{\circ}$ E), Atmos. Chem. Phys., 7, 4733-4749, 2007, http://www.atmos-chem-phys.net/7/4733/2007/.

Van Roozendael, M., Wagner T., Richter, A., Pundt, I., Arlander, D. W., Burrows, J. P., Chipperfield, M. P., Fayt, C., Johnston, P V., Lambert, J. C., Kreher, K., Pfeilsticker, K., Platt, U., Pommereau, J. P., Sinnhuber, B. M., Tornkvist, K. K., and Wittrock, F.: Intercomparison of $\mathrm{BrO}$ measurements from ERS-2 GOME, ground-based and balloon platforms, Adv. Space. Res., 29, 22, 1161-1666, 2002.

von Glasow, R., Platt, U., Crutzen, P. J., von Kuhlmann, R., and Lawrence, M. G.: Impact of reactive bromine chemistry in the troposphere, Atmos. Chem. Phys., 4, 2481-2497, 2004, http://www.atmos-chem-phys.net/4/2481/2004/.

Wahner, A., Ravishankara, A., Sander, S., and Friedl, R.: Absorption cross section of $\mathrm{BrO}$ between 312 and $385 \mathrm{~nm}$ at 298 and 223 K, Chem. Phys. Lett., 152, 507-512, 1988.

Wamsley, P. R., Elkins, J. W., Fahey, D. W., Dutton, G. S., Volk, C. M. Myers, R. C., Montzka, S. A., Butler, J. H., Clarke, A. D., Fraser, P. J., Steele, L. P., Lucarelli, M. P., Atlas, E. L., Schauffler, S. M., Blake, D. R., Rowland, F. S., Sturges, W. T., Lee, J. M., Penkett, S. A., Engel, A., Stimpfle, R. M., Chan, K. R., Weisenstein, D. K., Ko, M. K. W., and Salawitch, R. J.: Distribution of halon-1211 in the upper troposphere and lower stratosphere and the 1994 total bromine budget, J. Geophys. Res., 103, D1, 1513-1526, 1998. 